\title{
Baby Guerilla
}

\author{
Feature Artist
}

$\mathbf{R}_{\text {aby Guerilla's mission is to liberate art from just the gallery or the }}$

Bicture frame and make it accessible to everyone. She loves the idea of setting art free, setting our souls free to dream and imagine and go floating across a wall. She seeks to create worlds, meaning out of mayhem and dreams from despair.

After graduating from VCA she was all set for life as a painter. Street art began as a hobby on the side that seemed to take on a life of its own then grew and grew. Now she sees the two media as complimentary. The possibilities for her drawings are infinite.

She sees drawing on walls as a beautiful challenge ... the challenge of space and constraints. Defying gravity, dancing with gravity. The love affair continues ... 